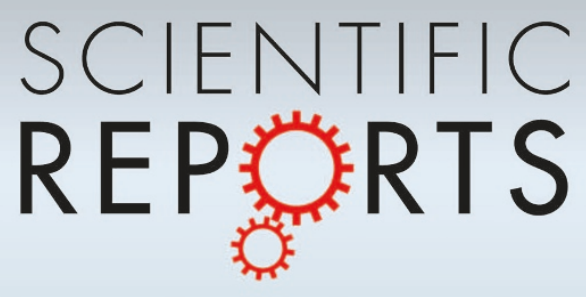

OPEN

SUBJECT AREAS:

PALAEOECOLOGY

EVOLUTIONARY ECOLOGY

Received

19 March 2014

Accepted

18 July 2014

Published

7 August 2014

Correspondence and requests for materials should be addressed to

R.B. (rblascolopez@ gmail.com)

\title{
The earliest pigeon fanciers
}

\author{
Ruth Blasco', Clive Finlayson', Jordi Rosell 2,3 , Antonio Sánchez Marco ${ }^{4}$ Stewart Finlayson', \\ Geraldine Finlayson', Juan José Negro ${ }^{5}$, Francisco Giles Pacheco ${ }^{6} \&$ Joaquín Rodríguez Vidal ${ }^{7}$
}

\begin{abstract}
'The Gibraltar Museum, 18-20 Bomb House Lane, P. O. Box 939, Gibraltar, ${ }^{2}$ Àrea de Prehistòria, Universitat Rovira i Virgili (URV), Avinguda de Catalunya 35, 43002 Tarragona, Spain, ${ }^{3}$ PHES, Institut Català de Paleoecologia Humana i Evolució Social, C/ Marcel.lí Domingo s/n - Campus Sescelades URV (Edifici W3), 43007 Tarragona, Spain, ${ }^{4}$ Area of Neogene and Quaternary Faunas, Institut Català de Paleontologia, Campus de la UAB, Cerdanyola del Vallès, Barcelona, Spain, ${ }^{5}$ Estación Biológica de Doñana (CSIC), Department of Evolutionary Ecology, Avda. Americo Vespucio s/n, 41092 Sevilla, Spain, ${ }^{6}$ Gibraltar Caves Project, 18-20 Bomb House Lane, P. O. Box 939, Gibraltar, ${ }^{7}$ Depto. Geodinámica y Paleontología, Facultad de Ciencias Experimentales, Campus del Carmen, Universidad de Huelva, Marine International Campus of Excellence - CEIMAR, 21071 Huelva, Spain.
\end{abstract}

Feral Pigeons have colonised all corners of the Earth, having developed a close association with humans and their activities. The wild ancestor of the Feral Pigeon, the Rock Dove, is a species of rocky habitats, nesting typically on cliff ledges and at the entrance to large caves. This habit would have brought them into close contact with cave-dwelling humans, a relationship usually linked to the development of dwellings in the Neolithic. We show that the association between humans and Rock Doves is an ancient one with its roots in the Palaeolithic and predates the arrival of modern humans into Europe. At Gorham's Cave, Gibraltar, the Neanderthals exploited Rock Doves for food for a period of over 40 thousand years, the earliest evidence dating to at least 67 thousand years ago. We show that the exploitation was not casual or sporadic, having found repeated evidence of the practice in different, widely spaced, temporal contexts within the cave. Our results point to hitherto unappreciated capacities of the Neanderthals to exploit birds as food resources on a regular basis. More so, they were practising it long before the arrival of modern humans and had therefore invented it independently.

$\mathrm{D}$ iscussion of the association of humans with commensal species usually considers mammal species, particularly as a prelude to domestication ${ }^{1}$. Birds are not usually discussed, other than with reference to species that were eventually domesticated, for example chickens (Gallus gallus domesticus ${ }^{2}$ ). In the case of mammals, the wolf (Canis lupus) is currently the species that appears to have had the longest association with humans, possibly dating back to at least 33 thousand years ago ${ }^{3}$. The earliest evidence of domestication, of goats (Capra hircus) and sheep (Ovis orientalis), is currently placed at 11 thousand years ago ${ }^{4}$. The Feral Pigeon (Columba livia) is the bird species which is most associated with humans, having adapted to urban life on all continents ${ }^{5}$. Morphologically, it is impossible to distinguish today between Feral Pigeons and the wild ancestor the Rock Dove - so that its natural geographical range cannot be determined ${ }^{6}$. Here, we show a clear connection between humans and Rock Doves from findings recovered at Gorham's Cave (Gibraltar). This connection predates modern humans and transcends human lineage boundaries.

\section{Geological, Chronological and Archaeological Setting: Gorham's Cave, Gibraltar}

Gibraltar $\left(36^{\circ} 7^{\prime} \mathrm{N}, 5^{\circ} 20^{\prime} \mathrm{W}\right)$ is located at the southern end of the Iberian Peninsula (Figure 1A). The western coast is sheltered by a wide bay, while the eastern side faces the Mediterranean Sea and is subjected to intense wave action. This particular phenomenon led to the creation and development of cavities of which Gorham's Cave is $\mathrm{one}^{7}$. Its sedimentary filling, from the deepest galleries to the present sea level, comprises a pure sandy aeolian record accumulated as a cliff-dune during climatic transgressive episodes. In the outermost area are frequent rock falls consisting of thin clast layers and seismic-like rock avalanches. In the inner sector the stratigraphy only displays local rock fall, aeolian dust, and karstic clay8 .

The first excavation was carried out at the outermost zone of the cave (entrance area) by Waechter ${ }^{910}$ and was characterised by a low density of archaeological remains. The sediments were composed of interbedded and irregular-layered bright red clayey sand, reddish brown clay/sand with abundant charcoal flecks, dark yellowish brown compact clay/sand, and tank/pink sands and clays ${ }^{11,12}$. Abundant limpets, other shells, and coarse, angular travertine roof falls occur within the lighter pink calcareous sandy units. The outer area was also excavated in its middle sector by Waechter, ${ }^{90}$ and later by Barton et al. ${ }^{13}$ and Stringer et al. ${ }^{14}$ (Figure 1B) and displays a lower sedimentation rate but also high human activity. These sediments tend to be somewhat less sandy than those in the outermost zone but are similar overall. In general, they include dark-brown organic-rich silty clay, grey sand, and irregularly bedded yellowish-brown sand containing coarse charcoal fragments; brown-black organic-rich 


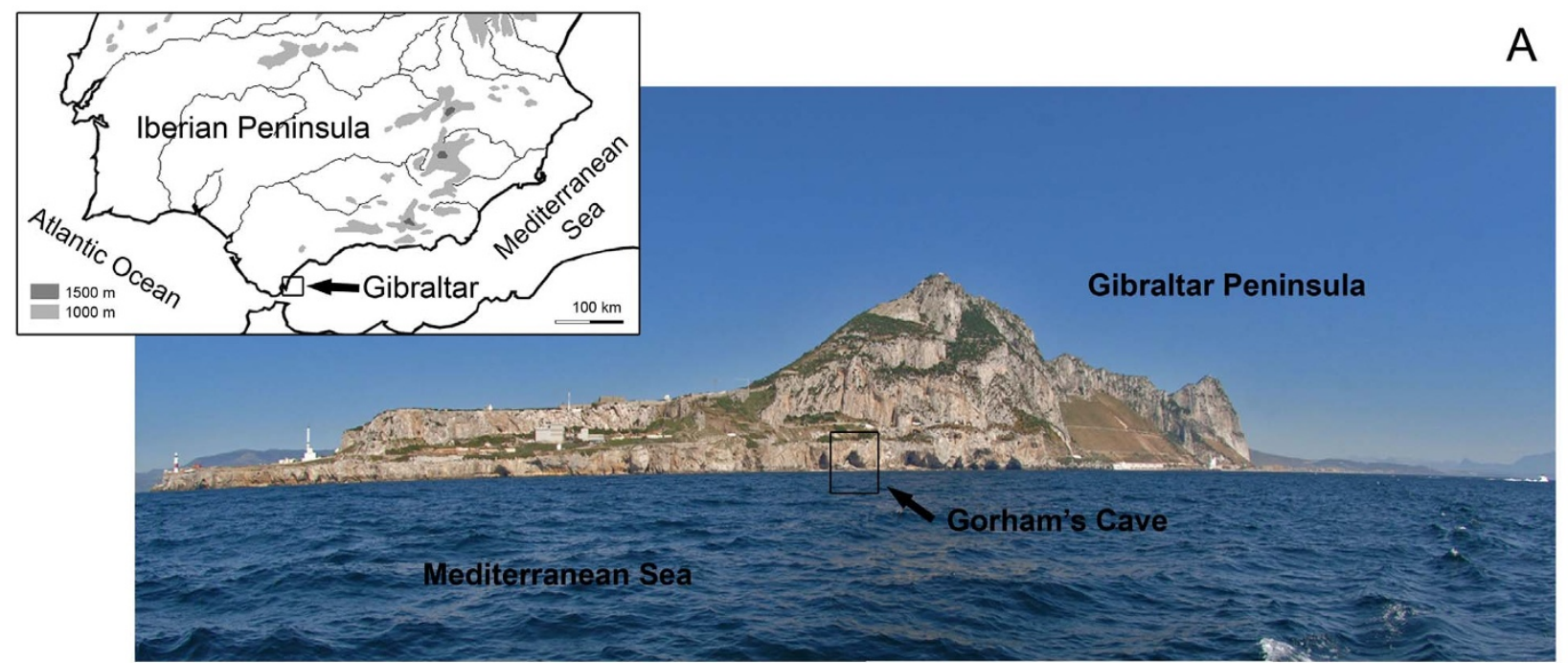

B
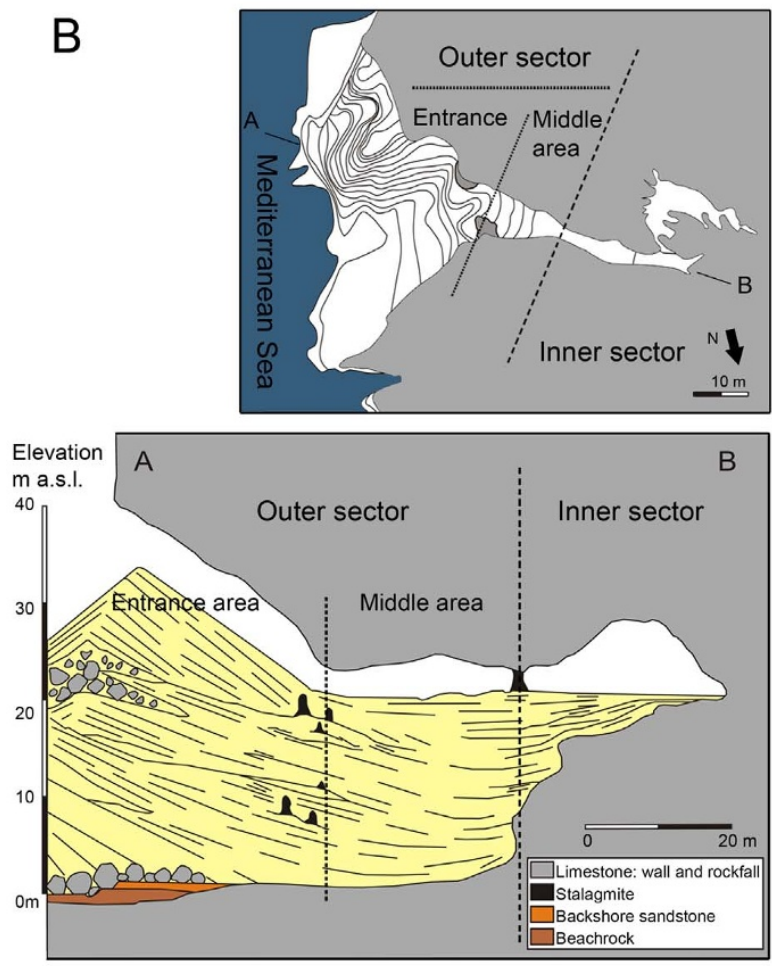

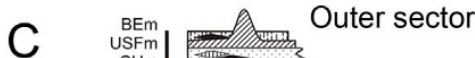

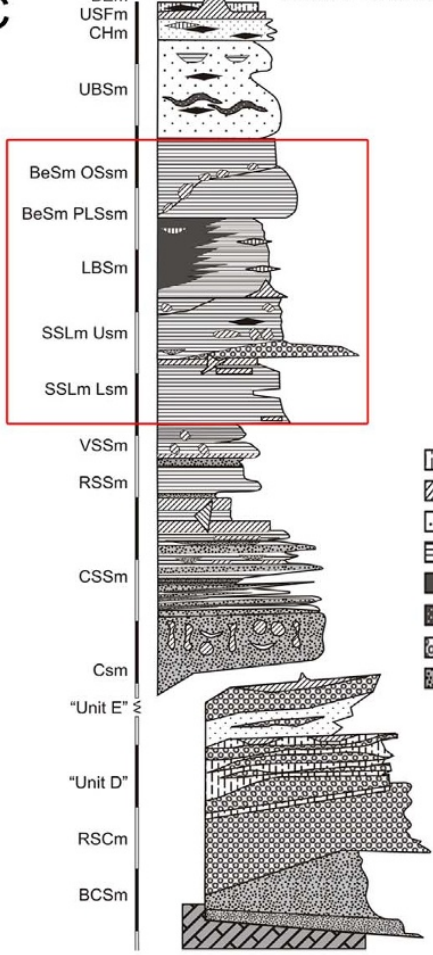

Inner sector

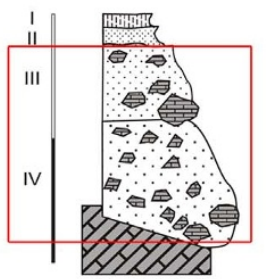

Subactual earthy material Stalagmite

Massive sand with clays Laminated sand Silt deposits Major bioturbations Breccia with limestone blocks Beach derived sand

Figure 1 (A) Location of Gorham's Cave, Gibraltar, in the southern Iberian Peninsula; (B) Top: General plan of Gorham's Cave showing the location of the excavated sectors [outer sector including the entrance and middle area of the cave, and inner sector (back of the cave)]; Bottom: Geological interpretative section of Gorham's Cave (NW-SE section or B-A projection in top) based on Jiménez-Espejo et al. ${ }^{7}$ and previous publications (e.g. ${ }^{9}{ }^{10,12,16}$ ); (C) Geological sequence of Gorham's Cave - left: schematic profile of the outer sector (middle area of the cave) modified from Collcut ${ }^{15}$ (see Barton et al. ${ }^{27}$ for more details); right: stratigraphic profile of the inner sector. Red boxes mark the archaeological levels/units studied here. The photograph in (A) was taken by C. Finlayson and the maps/graphs in (A, B) were made by J.R. and J.R.-V. by using CorelDRAW Graphics Suite 12 and CorelDRAW X3 software. We would like to acknowledge S.N. Collcut and R.N.E. Barton for the permission granted for the use of the geological sequence of Gorham's Cave shown in C-left, courtesy of the School of Archaeology, Oxford.

clay with whitish gritty phosphatic lenses; and interbedded, massive, homogeneous, coarse brown sand (see Collcut ${ }^{15}$ for more detail). The inner sector was excavated at the beginning of this century by the Gibraltar Museum, and the first results were published by Finlayson et al. ${ }^{16}$. The excavations exposed an area of about $29 \mathrm{~m}^{2}$ of cave floor and produced a stratigraphy with 4 main occupation levels (I-IV from top to bottom). The sedimentary record in this zone is thinner than in the outer part of the cave due to the higher position of the bedrock. Likewise, its sedimentary composition differs from other sectors due to a predominance of clay minerals, calcite, and quartz, with small quantities of dolomite, ankerite, and feldspars ${ }^{7}$. The inner sedimentary series seems to register a more condensed record than the outer zone, making the stratigraphic and chronological correlation between excavation areas difficult.

In the inner area, the chronology is based on a stratigraphically coherent series of AMS (Accelerator mass spectrometry) radiocarbon dates obtained from charcoal fragments. Level III is dated between ca. 12,640 and 10,880 BP for the Magdalenian horizon (level IIIa) and between $\mathrm{ca}$. 18,440 and 16,420 BP for the Solutrean horizon (level IIIb). Level IV is dated between ca. 32,560 and 23,780 $\mathrm{BP}^{15}$. In 
the outer area, a combination of AMS radiocarbon and OSL dates is used to locate chronologically the outer deposits. Radiocarbon results reported by Higham et al. ${ }^{17}$ indicate an age of between $c a .29$ and 51 kyr BP for UBSm.7 and BeSm.1. Nevertheless, the dates from the underlying LBSmff. $1-5$ of between ca. 42 and 56 Kyr BP suggest that most of the charcoal fragments from UBSm.7 and BeSm(OSsm) could have been moved up by the soft sediment loading ${ }^{17}$. The Single Grain (SG) OSL chronology and the Bayesian age model show sediments of MIS 5 age near the base of the sequence $(119,300 \pm$ $14800 \mathrm{kyr}$ for CSm), with deposition occurring into early to mid MIS3 (48,700 \pm 4000 for BeSm [PLSsm].3 and 38,500 $\pm 5800 \mathrm{kyr}$ for UBSm.6) ${ }^{18}$. The lowest layer studied here (SSLm [Usm].5) yielded an OSL age of $67,900 \pm 5150 \mathrm{kyr}^{18}$.

In the middle and lower layers of the outer stratigraphic sequence, lithic tools are consistent with the Middle Palaeolithic techno-complexes. The knapping technique follows discoid reduction sequences, although a significant increase of laminar flakes coming from bipolar Levallois cores can be detected at SSLm.5-6 (MIS 4). Lithic tools belonging to the Upper Palaeolithic were identified from CHm.5 (unite D of Waechter ${ }^{10}$; see Collcut and Currant ${ }^{19}$ for correlations). In the inner sector, level IV corresponds to a Mousterian horizon characterized by the use of flint and fine-grained sandstone and to a lesser extent quartzite, quartz, and dolomite. These materials are usually exploited following Levallois and discoid reduction sequences. In some cases, the obtained flakes are configured as scrapers, side-scrapers, and denticulates. A significant change can be detected at level III, which is characterized by a blade technology, plain retouch, and the configuration of artefacts that could be classified into the Upper Palaeolithic techno-complexes with diagnostic pieces attributable to the Solutrean and Magdalenian ${ }^{20,21}$.

The faunal record in Gorham's Cave is typically European (i.e., without African influences) and fairly constant in taxonomical composition through the sequence with no marked fluctuations of species per archaeological units, especially in the case of macro-mammals ${ }^{22}$. The majority of identified ungulate remains belong to two species Cervus elaphus and Capra ibex. This apparent stability of the environment surrounding the cave supports the hypothesis that southern Iberia did not suffer the extreme cold of glaciations or the aridity potentially generated by it. Only the occurrence of Grey Seal (Halichoerus grypus) registered by Sutcliffe in the D unit (CHm in Currant system; see Collcut and Currant ${ }^{19}$ for correlations) can be interpreted as punctual evidence of a cold phase since this species has never been previously recorded so far south ${ }^{22}$; this presence may simply reflect conditions to the north that may have forced some marine species south and not actual conditions on site. The amphibian and reptile assemblages from the inner part of the cave involve at least 24 taxa, including newts, toads, frogs, tortoises, turtles, lacertid and scincid lizards, geckos, and several snakes. These findings show an increase in the atmospheric temperature range during the latest Pleistocene, mainly due to lower winter temperatures ${ }^{23}$. The largest assemblage in the outer area comes from LBSmcf.11, which yielded 21 species with the southern spadefoot toad (Pelobates cultripes) as the most frequent taxa ${ }^{24}$. The small mammal record is remarkably stable with five dominant species - Oryctolagus cuniculus, Apodemus sylvaticus, Eliomys quercinus, Microtus brecciencis and Pitymys (Microtus) duodecimcostatus. In addition to these taxa, a selection of other species occurs in lower proportions though widely distributed through the stratigraphic sequence ${ }^{25}$.

Finally, the excavation works in the outer area produced a rich and diverse avifaunal assemblage, including at least 90 species (seabirds, ducks, birds of prey, partridges, waders, pigeons, swifts, crows, and small passerines) ${ }^{26}$. These taxa are especially concentrated on a relatively narrow section of the overall stratigraphic sequence (LBS Lower Bioturbated Sands). A typical core assemblage of common taxa is apparent throughout the sequence, consisting of partridge (Alectoris sp.), chough (Pyrrhocorax sp.), Common/Pallid Swift
(Apus apus/pallidus), and especially, Rock/Stock Dove (Columba livia/oenas $)^{26}$.

\section{Data Presentation and Results}

Here, we examined 1,724 Rock Dove bones from inner [III and IV levels] and outer [BeSm (Ossm).1 to SSLm (Usm).5] areas of Gorham's Cave (Figure 1C; Table S1; Table S2), spanning the time range from $67 \mathrm{kyr}$ to $28 \mathrm{kyr}^{16,27}$. This temporal range coincided with the occupation of the cave by Neanderthals and, subsequently, by modern humans. Twenty discrete archaeological units were examined taphonomically. Nineteen of these contexts were associated with Neanderthals and one with modern humans (level III from inner area $)^{16,27}$. We found evidence of human intervention on Rock Dove bones in 11 (57.89\%) of the Neanderthal contexts, as well as in the modern human context (Table 1). There was no observable difference in the tendency of damaged bones between Neanderthals and modern humans, both of whom appeared to have regularly processed Rock Doves, presumably for food. In the case of the Neanderthal occupation units, we detected cut-marks on 28 dove bones, 16 from level IV and 12 from the outer area (Table 1; Table S3; Figure 2). Incisions tend to occur both on the wing ( $n=22$ of 992 or $2.22 \%)$ and lower limb bones ( $n=5$ of 282 or $1.77 \%$ ), as well as on one sternum fragment (16.67\%) (Table S3; Figure 2). Although the proportion of cut-marked specimens is not high, it is important to emphasize that the size of these prey makes the use of stone tools unnecessary for direct consumption. After skinning or feather removal, direct use of hands and teeth would be the best way to remove the meat and fat/ cartilage from the bones ${ }^{28,29}$. The proof of this is the human toothmarks and associated damage observed on some dove bones $(n=15$ of 1364 or $1.1 \%)$. These imprints and alterations resulting from disarticulation and/or direct consumption (bone breakage by overextension, e.g., arrachement and peeling) match up with the anthropogenic alterations described both experimental and archaeologically by Lefèvre and Pasquet ${ }^{30}$, Higgins ${ }^{31}$, and Laroulandie ${ }^{32-34}$.

In addition, a proportion of the bird specimens show signs of burning ( $n=158$ of 1364 or $11.58 \%$ ), some of them with double colouring evidence ( $n=29$ of 158 burnt bones or $18.35 \%$ ) (Table S4). The latter alterations are due to the fact that the entire surface of the bone would not have been exposed to fire with the same intensity. This happens when the prey or portions of it (skinned or not) are placed on a fire place for roasting. The areas of the bone that have not meat on them (or only a very thin tissue), are affected by the heat more intensely, and therefore the degree of burning on these areas is higher. In contrast, the bone areas covered with large muscle mass remain unmodified or are modified only slightly, acquiring lower degrees of colouring. At Gorham's Cave, the double colouration on the dove bones coincides with the areas of the skeleton with low muscle mass. Thus, the highest grade of burning of the humerus is detected on the head of the proximal joint, on the distal end of the tibiotarsus and ulna, and on the distal part of the palmar surface of the radius. This type of evidence was also documented in the early Middle Palaeolithic of Bolomor Cave (Spain) $)^{28,35,36}$ and in sites with more recent chronologies, such as in the Upper Magdalenian site of La Vache (France) ${ }^{37}$ and at the Final Epigravettian levels of Grotta Romanelli (Italy) ${ }^{38}$. In these sites the presence of double colorations was interpreted as the result of birds being cooked over a fire or in burning embers. Although this practice seems to have been used by the Neanderthals of Gorham's Cave, the highest proportions of completely burnt bones belong to degree 2 (brown colour) and 3 (black colour) ( $n=139$ of 158 or $87.97 \%$ ). It must be taken into account that burning on bone fragments might reflect other types of intentional activities, such as the removal of waste for cleaning purposes, or could be the result of unintended processes, such as accidental burning. It could even be a consequence of post-depositional damage (e.g., secondary burning when fire places were set up on bones buried close to the surface). In the case of Gorham's Cave, it is possible that part of 
Table 1 | Number of specimens attributed to genus Columba (cf. Columba livia/oenas and Columba palumbus) from Gorham's Cave, Gibraltar. *Stratigraphic units/levels taken from Finlayson et al. ${ }^{16}$ and Barton et al. ${ }^{27} . * *$ Units containing Columba palumbus specimens: LBSmcf.2 = 2; LBSmcf.4 = 2; LBSmcf.5 = 3; LBSmcf.9 = 1; LBSmcf. $11=3$; LBSmcf. $13=1$; SSLm (Usm). $5=3$. NISP = Number of Identified Specimens; $\mathrm{MNE}=$ Minimal Number of Elements; $\mathrm{MNI}=$ Minimal Number of Individuals; $\mathrm{Cm}=$ Cut-marks; $\mathrm{B} \mathrm{Br}=\mathrm{Bone}$ breakage by overextension; Burn = Burned bones; Carniv = Carnivore damage. See Supplementary Material (Tables S1-S4) for more detail

\begin{tabular}{|c|c|c|c|c|c|c|c|c|c|c|c|c|}
\hline \multirow{2}{*}{ Site location area } & \multirow{2}{*}{ Stratigraphic units* } & \multicolumn{3}{|c|}{ Columba } & \multicolumn{4}{|l|}{$\mathrm{n}$} & \multicolumn{4}{|l|}{$\%$} \\
\hline & & NISP & MNE & MNI & $\mathrm{Cm}$ & $\mathrm{B} \mathrm{Br}$ & Burn & Carniv & $\mathrm{Cm}$ & $\mathrm{B} \mathrm{Br}$ & Burn & Carniv \\
\hline \multirow[t]{2}{*}{ Inner area } & III & 360 & 335 & 37 & 5 & 8 & 21 & 7 & 1.39 & 2.22 & 5.83 & 1.94 \\
\hline & IV & 481 & 426 & 55 & 16 & 6 & 43 & 8 & 3.33 & 1.25 & 8.94 & 1.66 \\
\hline \multirow[t]{19}{*}{ Outer area } & BeSm (Ossm). 1 & 2 & 2 & 1 & & & & & & & & \\
\hline & $\mathrm{BeSm}$ (PLSsm). 3 & 81 & 70 & 8 & 2 & & 9 & 2 & 2.47 & & 11.11 & 2.47 \\
\hline & LBSmff. 1 (fine facies) & 10 & 9 & 3 & & & & & & & & \\
\hline & LBSmcf. 1 (coarse facies) & 3 & 2 & 1 & & & 1 & & & & 33.33 & \\
\hline & LBSmcf. $2 * *$ & 116 & 93 & 12 & 5 & 2 & 27 & & 4.31 & 1.72 & 23.28 & \\
\hline & LBSmcf. $4 * *$ & 195 & 157 & 22 & 2 & 5 & 58 & & 1.03 & 2.56 & 29.74 & \\
\hline & LBSmcf. 1-4 general & 11 & 9 & 2 & & & & & & & & \\
\hline & LBSmcf. $5 * *$ & 52 & 47 & 7 & & 1 & 5 & & & 1.92 & 9.62 & \\
\hline & LBSmcf.6 & 17 & 17 & 3 & & & & & & & & \\
\hline & LBSmcf.7 & 22 & 20 & 2 & & & 2 & & & & 9.09 & \\
\hline & LBSmcf.8 & 47 & 41 & 3 & 1 & & 3 & & 2.13 & & 6.38 & \\
\hline & LBSmcf.9** & 160 & 130 & 15 & & 1 & 4 & & & 0.63 & 2.50 & \\
\hline & LBSmcf. 10 & 3 & 3 & 1 & & & & & & & & \\
\hline & LBSmcf. 11 ** & 58 & 53 & 8 & & & & 1 & & & & 1.72 \\
\hline & LBSmcf. 12 & 29 & 27 & 4 & & & 4 & & & & 13.79 & \\
\hline & LBSmcf. 13** & 8 & 8 & 3 & & & & 1 & & & & 12.50 \\
\hline & SSLm (Usm).3 & 2 & 2 & 1 & & & & & & & & \\
\hline & $\mathrm{SSLm}\left(\mathrm{Usm}_{\mathrm{sm}}\right) .5^{* *}$ & 67 & 58 & 10 & 2 & & 2 & 2 & 2.99 & 0.00 & 2.99 & 2.99 \\
\hline & & 1724 & 1509 & 198 & 33 & 23 & 179 & 21 & 1.91 & 1.33 & 10.38 & 1.22 \\
\hline
\end{tabular}

the burning might be the result of non-nutritive events that occurred after consumption and/or deposition. In contrast, modifications by other agents, such as carnivores, were negligible. Only $0.81 \%(n=$ 11) of all the elements showed marks by carnivore gnawing, and $0.22 \%(n=3)$ showed damage due to digestive action by birds of prey. Only in layers LBSmcf.11 and LBSmcf.13 was there no evidence of human exploitation while carnivore modifications were documented. Carnivore damage was represented by a unique tooth-marked dove specimen in each layer. Despite this lack of anthropogenic damage on Columba bones, other ungulate taxa showed human processing in LBSmcf.11, which yielded one burnt cervid metatarsal fragment and a Cervus elaphus radius shaft fragment retoucher ${ }^{22}$. Besides, both LBSmcf.11 and LBSmcf.13 displayed a significant collection of lithic industry following discoid and Levallois reduction sequences $^{39}$.

\section{Discussion and Conclusions}

Our results demonstrate unequivocally that Neanderthals, and later on modern humans, consumed Rock Doves. Furthermore, this was not an isolated or casual behaviour as it affected a significant number of individual doves over a long temporal period. It points to the origin of an association, within the context of caves, which has persisted to the present day. Until now, the systematic exploitation of birds has been considered to be an exclusive and defining feature of modern human behaviour ${ }^{40}$, although recent evidence has pointed to the regular exploitation of raptors and corvids (for feathers) by Neanderthals in Gorham's Cave ${ }^{41}$. There is also evidence of the use of feathers in Grotta di Fumane (MIS 3, Italy) ${ }^{42}$ and of raptor claws in Combe-Grenal (MIS 5b, France) and Les Fieux (MIS 3, France) ${ }^{43}$. The exploitation of pigeons could date as far back as the Middle Pleistocene from evidence of level IV of Bolomor Cave with 2 butchered individuals of Columba sp. (MIS 5e, Spain) ${ }^{35,36}$ and from UA25 of Lazaret Cave with one processed specimen of Columba livia (MIS 6 , France) ${ }^{44,45}$. These are, nevertheless, isolated events in comparison with the diachronic consistency observed at Gorham's Cave. The regular use of Rock Doves for food is presented here for the first time from 11 distinct Neanderthal occupation units from Gorham's Cave. The lack of anthropogenic damage on dove bones in the 8 remaining layers might be explained by diverse factors. A potential problem is that human activities on small prey do not always leave tell-tale physical evidence on all bones ${ }^{46}$. Apart from the fact that the lithic tool does not always come into contact with the bone, birds can be butchered (after skinning and de-feathering) using only the teeth and hands, which often makes it difficult to distinguish these alterations from those generated by other predators. In this connection, it must also be considered that differences in occupational patterns (mobility and site functionality), socio-cultural factors, and/or human behavioural diversity could condition the range of exploited species. That is, Neanderthals could have developed different subsistence strategies in the same landscape depending on behavioural variables, which are difficult to control archaeologically ${ }^{36}$. Taking all the variables with the potential to obscure human intervention signals, in the case of Gorham's Cave we interpret the 11 Mousterian occupation units with human use of pigeons as the strongest currently available evidence of a recurrent and systematic behaviour by Neanderthals in a specific area.

However, ascertaining archaeologically the way Rock Doves were procured is difficult, as different methods could have left no trace in the fossil record. But even if birds may be perceived as elusive prey due to their flight capabilities, no technology needs to be invoked for their capture. Birds are forced to incubate their eggs in a fixed position, the nest, where the nestlings grow until they reach full adult size (for altricial birds such as the pigeon). This makes eggs, nestlings and brooding adults relatively easy to catch by hand by a moderately skillful and silent climber. Even roosting birds at night are practically defenseless against stealth predators because birds rely on vision and/ or hearing for protection against predators, and contrary to mammals they cannot exploit olfactory cues. Ethnographic examples indicate that hunter-gatherers often catch wild birds as bushmeat ${ }^{47}$. To catch birds, modern humans in traditional societies use a variety of 

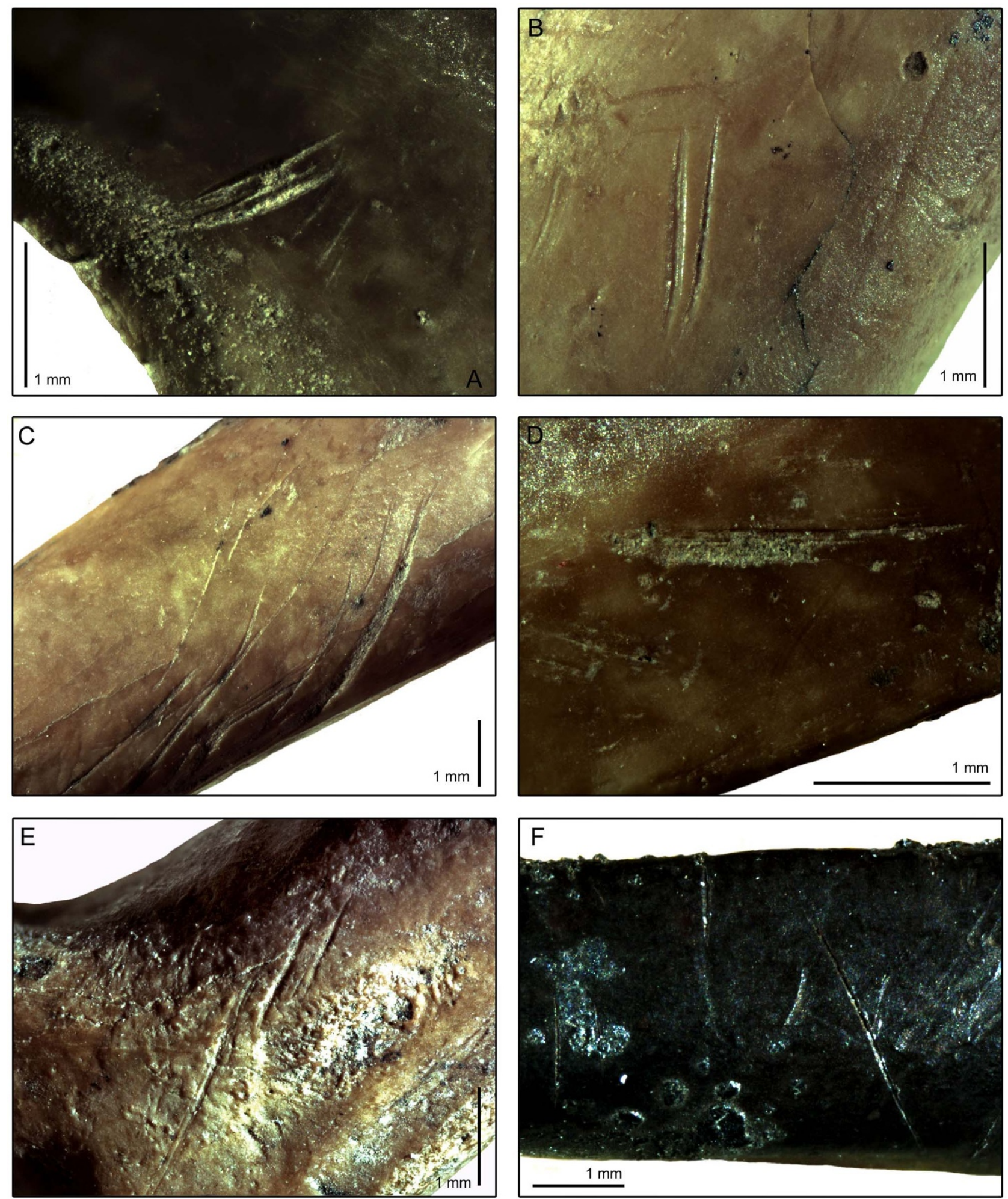

Figure $2 \mid$ Cut-marked bones of Rock Dove specimens from Gorham's Cave: sternum (A), ulna (B, E) and humerus (C, D) from level IV, and tibiotarsus from LBSmcf.2 (F). Note burning damage (Degree 3 -black colour) on tibiotarsus (F).

bird traps (typically snares or netting systems baited with food), sometimes in combination with the imitation of bird calls by direct vocalization or by using whistles to attract individuals from far away $^{48,49}$. In any case, active collection by hand or by different hunting techniques would not be mutually exclusive with the occasional scavenging of dead animals in the cliff. Nevertheless, their relatively high decomposition rate, i.e., rapid decomposition ${ }^{50}$, and the low incidence of carnivores detected from their bones could relate to immediate access by human groups to these animals. Even with this, it is possible that pigeons were easier to catch than other quick-flying animals. However, evidence of exploitation of avian species presumably harder to catch (e.g., raptors and corvids) was previously reported in Finlayson et al. ${ }^{41}$ for the same site. Similar observations were also made in other Neanderthal contexts of France and Italy ${ }^{42,43}$. Some cut-marked species coming from these studies are, for example, Aquila chrysaetos, Gypaetus barbatus, Aegypius monachus, 
Gyps fulvus, Falco vespertinus, Milvus milvus, and Pyrrhocorax pyrrhocorax/graculus. This core of evidence provides clear proof that Neanderthal cognitive capacities to obtain different avian taxa were comparable to those of modern humans. Thus, the exploitation of pigeons reported here is further evidence that puts the Neanderthals' abilities on par with those of modern humans.

The Rock Dove is a colonial and fast-reproducing species, making it an ideal candidate for sustainable exploitation. The nesting habit of the Rock Dove and its distribution in the landscape are practically unique in the Palearctic ${ }^{51}$ : the species is highly colonial any time of the year in any kind of cliff or rocky outcrop, inland or on the coast ${ }^{6}$. Few bird species are comparable in numbers and ubiquity. Seabirds are colonial species which are invariably linked to coastal areas, and other colonial bird species, such as herons, ibises, flamingos, and waterfowl, breed and forage necessarily in wetlands; corvids are forest birds, and a few colonial species, such as Jackdaws or choughs, that may breed in rocky outcrops or cliffs do not seem capable of reaching such high population densities as doves ${ }^{52}$. Other colonial birds, such as starlings, sparrows, swifts, and swallows, are again highly seasonal in their breeding and too small in size to have become staple prey. Furthermore, pigeon nesting colonies and foraging flocks have practically no upper limit in size. Even today, millions of birds may flock together, as in Argentina ${ }^{53}$, and the largest flocks ever registered for any bird species were those of the now extinct passenger pigeon ${ }^{54}$. The original distribution range of the Rock Dove includes the mid-latitude belt in Eurasia, and the overlap with the Neanderthal range would have been extensive. Few species of birds had the potential to become so abundant within the distribution range of the Neanderthals. In short, it seems that the Neanderthals living in Gorham's Cave regularly took this bird for food, and it was one of a small suite of species with similar characteristics that would have guaranteed a stable food supply in the rocky environment of the Gibraltar landscape, as probably in many other parts of the Neanderthal geographical range. Traditionally in human history, the pigeon has been considered a symbol of peace, love, and fertility ${ }^{55}$, three attributes that are deeply interwoven. Its origins may well have been with the Neanderthals who exploited this very fertility in a way that allowed them to target them for food without depleting their numbers.

\section{Methods Summary}

Surface alterations were treated at both macroscopic and microscopic level (optical light microscope, Nikon SMZ 1500 - magnification to $125 \times$ ). Selected items were examined with an analytical FEI QUANTA 600 Environmental Scanning Electron Microscope (ESEM). Damage observed on dove remains included cut-marks (e.g. ${ }^{56,57}$ ), fresh bone breakage, over-extending, burning, and human tooth-marks. Fresh bone breakage on bird remains can be the result of several processes, such as disarticulation or removal of marrow, fat, and cartilage. These phenomena generate certain damage, such as peeling, notches, and/or arrachement. Peeling is defined as a roughened surface with parallel grooves and fibrous texture and is characterized by a superficial flaking on the bone. Arrachement is the loss of bone cortical tissue related to dismembering by means of hyperextending the elbow. This activity produces a breakdown of the olecranon fossa of the humerus and of the proximal joints of the radius and ulna ${ }^{58}$. In addition, humans can also leave tooth marks on bird bones as a consequence of direct consumption of meat, fat, or cartilage ${ }^{28,29,34,35}$. Given the risk of confusion with carnivore gnawing, we identified human tooth-marks on the basis of the criteria proposed by Laroulandie ${ }^{34}$ and made a systematic comparison with bone damage generated by carnivores. Carnivore alterations were analysed following the observations described by Bochenski and Tomek ${ }^{59}$ and Bochenski et al. ${ }^{60}$. Burning damage was analysed in terms of presence/absence and based mainly on colour changes and other physical alterations produced during exposure to fire, such as cracks and fissures (e.g. ${ }^{33,34,37}$ ). The degree of alteration from burning was designated according to six categories of intensity, with degree 0 being unburned bones and degree 5 being calcined ones.

1. Clutton-Brock, J. A Natural History of Domesticated Mammals (Cambridge University Press, Cambridge, 1999).

2. Liu, Y.-P. et al. Multiple maternal origins of chickens: Out of the Asian jungles. Mol. Phylog. Evol. 38, 12-19 (2006).

3. Druzhkova, A. S. et al. Ancient DNA Analysis Affrims the Canid from Altai as a primitive Dog. PLoS One 8, e57754 (2013).
4. Zeder, M. A. Domestication and early agriculture in the Mediterranean Basin: Origins, diffusion, and impact. PNAS 105, 11597-11604 (2008).

5. Larson, D. et al. The Urban Cliff Revolution. New Findings on the origins and Evolution of Human Habitats (Fitzhenry \& Whiteside, Markham, 2004).

6. Cramp, S. \& Simmons, K. E. L. Handbook of the birds of Europe, the Middle East, and North Africa - The birds of the western Palearctic (Oxford University Press, Oxford, 1985).

7. Jiménez-Espejo, F. J. et al. Environmental conditions and geomorphologic changes during the Middle-Upper Paleolithic in the southern Iberian Peninsula. Geomorphology 180-181, 205-216 (2013).

8. Rodríguez-Vidal, J. et al. Neotectonics and shoreline history of the Rockof Gibraltar, southern Iberia. Quat Sci Rev 23, 2017-2029 (2004).

9. Waechter, J. d'A. The Excavations at Gorham's Cave, Gibraltar, preliminary report for the seasons 1948 and 1950. Proceedings of the Prehistoric Society NS 17, 83-92 (1951).

10. Waechter, J. d'A. The Excavations at Gorham's Cave, Gibraltar, 1951-1954. Bull Inst Arch London 4, 189-221 (1964).

11. Macphail, R. I. \& Goldberg, P. Geoarchaeological investigation of sediments from Gorham's and Vanguard Caves, Gibraltar: Microstratigraphical (soil micromorphological and chemical) signatures. In: Stringer, C. B., Barton, R. N. E \& Finlayson, J. C. (Eds.), Neanderthals on the Edge. [183-200] (Oxford, Oxbow Books, 2000).

12. Goldberg, P. \& Macphail, R. I. Micromorphology of Sediments from Gibraltar Caves: Some Preliminary Results from Gorham's Cave and Vanguard Cave. In: Finlayson, C., Finlayson, G. \& Fa, D. (Eds.), Gibraltar during the Quaternary: the southernmost part of Europe in the last two million years [93-108] (Gibraltar Government Heritage Publications, Gibraltar, 2000).

13. Barton, R. N. E. et al. Gibraltar Neanderthals and results of recent excavations in Gorham's Vanguard and Ibex Cavc, Antiquity 73, 13-23 (1999).

14. Stringer, C. B. et al. Gibraltar Palaeolithic Revisited: New Excavations at Gorham's and Vanguard Caves. In: Davies, W. \& Charles, R. (Eds.), Dorothy Garrod and the Progress of the Palaeolithic. Studies in the Prehistoric Archaeology of the Near East and Europe [84-96] (Oxbow Books, Oxford, 1999).

15. Collcut, S. N. Gorham's Cave lithological and lithogenetic patterns. In: Barton, R. N. E., Stringer, C. B. \& Finlayson, J. C. (Eds.), Neanderthals in Context: A Report of the 1995-1998 Excavations at Gorham's and Vanguard Caves, Gibraltar [37-49] (Oxford University Press, Oxford, 2013).

16. Finlayson, C. et al. Late survival of Neanderthals at the southern most extreme of Europe. Nature 443, 850-853 (2006).

17. Higham, T. F. G. et al. The radiocarbon chronology of Gorham's Cave. In: Barton, R. N. E., Stringer, C. B. \& Finlayson, J. C. (Eds.), Neanderthals in Context: A Report of the 1995-1998 Excavations at Gorham's and Vanguard Caves, Gibraltar [62-76] (Oxford University Press, Oxford, 2013).

18. Rhodes, E. J. OSL dating of sediments from the lower part of Gorham's Cave. In: Barton, R. N. E., Stringer, C. B. \& Finlayson, J. C. (Eds.), Neanderthals in Context: A Report of the 1995-1998 Excavations at Gorham's and Vanguard Caves, Gibraltar [77-88] (Oxford University Press, Oxford, 2013).

19. Collcut, S. N. \& Currant, A. P. Gorham's Cave lithostratigraphy. In: Barton, R. N. E., Stringer, C. B. \& Finlayson, J. C. (Eds.), Neanderthals in Context: A Report of the 1995-1998 Excavations at Gorham's and Vanguard Caves, Gibraltar [15-36] (Oxford University Press, Oxford, 2013).

20. Giles Pacheco, F. et al. The tools of the last Neanderthals: Morphotechnical characterization of the lithic industry at level IV of Gorham's Cave, Gibraltar. Quatern. Int. 247, 151-161 (2012).

21. Shipton, C. et al. Variation in lithic technological strategies among the Neanderthals of Gibraltar. PLoS One 8, e65185 (2013).

22. Currant, A. P. et al. The large mammal remains from Gorham's Cave. In: Barton, R. N. E., Stringer, C. B. \& Finlayson, J. C. (Eds.), Neanderthals in Context: A Report of the 1995-1998 Excavations at Gorham's and Vanguard Caves, Gibraltar [141-150] (Oxford University Press, Oxford, 2013).

23. Blain, H.-A. et al. Climatic conditions for the last Neanderthals: Herpetofaunal record of Gorham's Cave, Gibraltar. J Hum Evol 64, 289-99 (2013).

24. Gleed-Owen, C. P. \& Price, C. Amphibians and reptiles from Gorham's Cave. In: Barton, R. N. E., Stringer, C. B. \& Finlayson, J. C. (Eds.), Neanderthals in Context: A Report of the 1995-1998 Excavations at Gorham's and Vanguard Caves, Gibraltar [102-111] (Oxford University Press, Oxford, 2013).

25. Price, C. The small mammal fauna of Gorham's Cave. In: Barton, R. N. E., Stringer, C. B. \& Finlayson, J. C. (Eds.), Neanderthals in Context: A Report of the 1995-1998 Excavations at Gorham's and Vanguard Caves, Gibraltar [128-140] (Oxford University Press, Oxford, 2013).

26. Cooper, J. H. The late Pleistocene avifauna of Gorham's Cave and its environmental correlates. In: Barton, R. N. E., Stringer, C. B. \& Finlayson, J. C. (Eds.), Neanderthals in Context: A Report of the 1995-1998 Excavations at Gorham's and Vanguard Caves, Gibraltar [112-127] (Oxford University Press, Oxford, 2013).

27. Barton, R. N. E., Stringer, C. B. \& Finlayson, J. C. Neanderthals in Context: A Report of the 1995-1998 Excavations at Gorham's and Vanguard Caves, Gibraltar (Oxford University Press, Oxford, 2013).

28. Blasco, R. \& Fernández Peris, J. Middle Pleistocene bird consumption at Level XI of Bolomor Cave (Valencia, Spain). J. Archaeol. Sci. 36, 2213-2223 (2009).

29. Laroulandie, V. Les traces liées à la boucherie, à la cuisson et à la consommation d'oiseaux. Apport d l'expérimentation. In: Bourguignon, L., Ortega, I. \& Frère- 
Sautot, M.-C. (Eds), Préhistoire et approche expérimentale [97-108] (Collection préhistoire 5. Montagnac: Monique Mergoual, 2001).

30. Lefèvre, C. \& Pasquet, E. Les modifications post-mortem chez les oisseaux: l'example de l'avifaune holocène de Patagonie australe. Artefacts 9, 217-229 (1994).

31. Higgins, J. Túnel: a case study of avian zooarchaeology and taphonomy. J. Archaeol. Sci. 26, 1449-1457 (1999).

32. Laroulandie, V. Etudes archéozoologique et taphonomique des Lagopédes des Saules de la Grotte magdaléniennes des Eglises (Ariége). Anthropozool. 28, 45-54 (1998).

33. Laroulandie, V. Taphonomie et archéozoologie des oiseaux en grotte: applications aux sites paléolithiques du Bois Ragot (Vienne), de Combe Saunière (Dordogne) et de La Vache (Ariège) (Ph D. Universite Bordeaux-I, France, 2000).

34. Laroulandie, V. Anthropogenic versus non-anthropogenic bird bone assemblages: new criteria for their distinction (Oxbow Books, Oxford, 2005).

35. Blasco, R. \& Fernández Peris, J. A uniquely broad spectrum diet during the Middle Pleistocene at Bolomor Cave (Valencia, Spain). Quatern. Intern. 252, 16-31 (2012).

36. Blasco, R. et al. Environmental availability, behavioural diversity and diet: a zooarchaeological approach from the TD10-1 sublevel of Gran Dolina (Sierra de Atapuerca, Burgos, Spain) and Bolomor Cave (Valencia, Spain). Quatern. Sci. Rev. 70, 124-144 (2013).

37. Laroulandie, V. Bird explotaition pattern: the case of Ptarningan Lagopus sp. in the Upper Magdalenian site of la Vache (Ardiège, France). In: Grupe, G. \& Peters, J. (Eds.), Feathers, Grid and Symbolism Birds and Humans in the Ancient Old and New Worlds [165-178] (Proceedings of the 5th. Meeting of the ICAZ, Munich, 2005).

38. Cassoli, F. \& Tagliacozzo, A. Butchering and cooking of birds in the Palaeolithic site of Grotta Romanelli (Italy). Int. J. Osteoarchaeol. 7, 303-320 (1997).

39. Barton, R. N. E. \& Jennings, R. The lithic artefacts assemblages of Gorham's Cave. In: Barton, R. N. E., Stringer, C. B. \& Finlayson, J. C. (Eds.), Neanderthals in Context: A Report of the 1995-1998 Excavations at Gorham's and Vanguard Caves, Gibraltar [151-187] (Oxford University Press, Oxford, 2013).

40. Klein, R. G. The Human Career (University of Chicago Press, Chicago, 1989).

41. Finlayson, C. et al. Birds of a feather: Neanderthal exploitation of raptors and corvids. Plos One 7, e45927 (2012).

42. Peresani, M. et al. Late Neandertals and the intentional removal of feathers as evidenced from bird bone taphonomy at Fumane Cave 44 ky B.P., Italy. PNAS 108, 3888-3893.

43. Morin, E. \& Laroulandie, V. Presumed symbolic use of diurnal raptors by neanderthals. Plos One 7, e32856 (2012).

44. Lumley, H. de. Le Sol d'Occupation Acheuléen de l'Unité archéostratigraphique UA 25 de La Grotte du Lazaret (EDISUD, Aix-en-Provenza, 2004).

45. Roger, T. L'avifaune du Pléistocène moyen et supèrieur du bord de la Meéditerranèe européenne: Orgnac 3, Lazaret (France), Caverne delle Fate, Arma delle Manie (Italie), Kalamakia (Greèce), Karain E (Turquie), Paléontologie, Taphonomie et Paléoécologie (Ph.D. thesis, Institut de Paléontologie Humaine, Musèum National d'Histoire Naturel, 2004).

46. Steadman, D. W., Plourde, A. \& Burley, D. V. Prehistoric butchery and consumption of birds in the kingdom of Tonga, South Pacific. J Archaeol Sci 29, 571-584 (2002).

47. Juste, J., Fa, J. E., Perez del Val, J. \& Castroviejo, J. Market dynamics of bushmeat species in Equatorial Guinea. J Appl Ecol 32, 454-467 (1995).

48. Lévi-Strauss, C. Tristes Troópicos (Ediciones Paidós Ibeérica S.A., Barcelona, 1992).

49. Emperaire, J. Los nómades del mar (Lom Ediciones, Santiago, 2002).

50. Bunbury, N. et al. Causes of mortality in free-living Mauritian pink pigeons Columba mayeri, 2002-2006. Endang Species Res 9, 213-220 (2008).
51. Finlayson, C. Neanderthals and Modern Humans. An Ecological and Evolutionary Perspective (Cambridge University Press, Cambridge, 2004).

52. Martí, R. \& Del Moral, J. C. Atlas de las Aves Reproductoras de España (Dirección General de Conservación de la Naturaleza-Sociedad Española de Ornitología, Madrid, 2003).

53. Murton, R. K. et al. The ecology of the eared dove (Zenaida Auriculata) in Argentina. The Condor 76, 80-88 (1974).

54. Ehrlich, P. R. et al. The Passenger Pigeon (Stanford University, Stanford, 1988).

55. Cocker, M. \& Tipling, D. Birds and People (Johnatan Cape, London, 2013).

56. Shipman, P. \& Rose, J. Early hominid hunting, butchering and carcass-processing behaviors: approaches to the fossil record. J. Anthropol. Archaeol. 2, 57-98 (1983).

57. Lyman, R. J. Quantitative Paleozoology (Cambridge University Press, Cambridge, 2008).

58. Laroulandie, V. et al. Quand désarticuler laisse des traces: le cas de l'hyperextension du coude. Annales de Paléontologie 94, 287-302 (2008).

59. Bochenski, Z. M. \& Tomek, T. Preservation of bird bones: erosion versus digestion by owls. Int. J. Osteoarchaeol. 7, 372-387 (1997).

60. Bochenski, Z. M. et al. Damage to bird bones in pellets of gyrfalcon Falco rusticolus. J. Archaeol. Sci. 25, 425-433 (1998).

\section{Acknowledgments}

The excavations and scientific research associated with Gorham's and Vanguard Caves were funded by HM Government of Gibraltar. This research was also supported by funding from the Spanish Ministry of Science and Innovation-FEDER, project nos.

CGL2012-38434-C03-03, CGL2012-38358, CGL-BOS-2012-34717. R. Blasco is a Beatriu de Pinós post-doctoral research fellowship recipient (Generalitat de Catalunya and COFUND Marie Curie Actions, EU-FP7). We would like to acknowledge S.N. Collcut and R.N.E. Barton for the permission granted for the use of the geological sequence of Gorham's Cave shown in Figure 1C-left, courtesy of the School of Archaeology, Oxford. The funders had no role in study design, data collection, analysis, decision to publish, or preparation of the manuscript.

\section{Author contributions}

C.F. designed the project. C.F. and R.B. coordinated and wrote the manuscript. A.S.M. identified taxonomically the bird specimens from the Inner sector of Gorham's Cave and R.B. and J.R. analysed taphonomically the Rock Dove specimens. S.F., G.F., F.G.P. and J.R.V. participated in the excavation and research project. J.J.N., S.F. and G.F. provided contextual data. All authors discussed and commented on the manuscript.

\section{Additional information}

Supplementary information accompanies this paper at http://www.nature.com/ scientificreports

Competing financial interests: The authors declare no competing financial interests. How to cite this article: Blasco, R. et al. The earliest pigeon fanciers. Sci. Rep. 4, 5971; DOI:10.1038/srep05971 (2014).

This work is licensed under a Creative Commons Attribution-NonCommercialNoDerivs 4.0 International License. The images or other third party material in this article are included in the article's Creative Commons license, unless indicated otherwise in the credit line; if the material is not included under the Creative Commons license, users will need to obtain permission from the license holder in order to reproduce the material. To view a copy of this license, visit http:// creativecommons.org/licenses/by-nc-nd/4.0/ 